\title{
NEOECHINORHYNCHUS PIMELODI SP.N. (EOACANTHOCEPHALA, NEOECHINORHYNCHIDAE) PARASITIZING PIMELODUS MACULATUS LACÉPĖDE, "MANDI-AMARELO" (SILUROIDEI, PIMELODIDAE) FROM THE BASIN OF THE SÃO FRANCISCO RIVER, TRÊS MARIAS, MINAS GERAIS, BRAZIL
}

\author{
Marilia de Carvalho Brasil-Sato ${ }^{1}$ \\ Gilberto Cezar Pavanelli ${ }^{2}$
}

\begin{abstract}
Neoechinorhynchus pimelodi sp.n. is described as the first record of Acanthocephala in Pimelodus maculatus Lacépède, 1803, collected in the São Francisco river, Três Marias, Minas Gerais. The new species is distinguished from other of the genus by the three circles of hooks of different sizes, and by the eggs measurements. The hooks measuring 100-112 (105), 32-40 (36) and 20-27 (23) in length in the males and 102-142 (129), 34-55 (47) and 27-35 (29) in length in the females for the anterior, middle and posterior circles. The eggs measuring 15-22 (18) in length and 12-15 (14) in width, with concentric layers of texture smooth, enveloping the acanthor.

KEY WORDS. Acanthocephala, Neoechinorhynchidae, Neoechinorhynchus pimelodi sp.n., Pimelodus maculatus, São Francisco river, Brazil
\end{abstract}

Among the Acanthocephala species listed in the genus Neoechinorhynchus Hamann, 1892 by GolvaN (1994), the following parasitize freshwater fishes in Brazil: Neoechinorhynchus buttnerae Golvan, 1956, N. paraguayensis Machado Filho, 1959, N. pterodoridis Thatcher, 1981 and N. golvani Salgado-Maldonado, 1978, in the Amazon Region, N. curemai Noronha, 1973, in the states of Pará, Amazonas and Rio de Janeiro, and N. macronucleatus Machado Filho, 1954, in the state of Espirito Santo. In the present report Neoechinorhynchus pimelodi sp.n. infecting Pimelodus maculatus Lacépède, 1803 (Siluroidei, Pimelodidae), collected in the São Francisco River, Três Marias, Minas Gerais, Brazil is described. This is the first report of Acanthocephala for P. maculatus.

\section{MATERIAL AND METHODS}

In July 1995 and in January 1996, 123 specimens of P. maculatus (mandiamarelo) were hook-fished in the basin of the São Francisco River in the region of Três Marias, Minas Gerais, Brazil. The fish were identified according to BRITSKI et

1) Departamento de Biologia Animal, Universidade Federal Rural do Rio de Janeiro. Caixa Postal 74539, 23851-970 Seropédica, Rio de Janeiro, Brasil.

2) Departamento de Biologia, Núcleo de Pesquisa em Limnologia, Ictiologia e Aqüicultura, Universidade Estadual de Maringá. 87020-900 Maringá, Paraná, Brasil. 
al. (1984), kept in tanks and necropsied at the Laboratory of the CODEVASF in Três Marias. Necropsies were performed on fish measuring 13.5 to $31 \mathrm{~cm}$ in length and weighing 15 to $265 \mathrm{~g}$. Acanthocephalans were isolated on Petri dishes with distilled water, refrigerated for 24 hours, fixed in A.F.A. for 24 hours, and stored in $70^{\circ} \mathrm{GL}$ alcohol. After the selection of male, mature female and juvenile specimens, the specimens were stained with Mayer carmalumen, dehydrated in a ascending alcohol series, cleared in Faia creosote and mounted with Canada balsam. Reproductive systems with mature and selected eggs, were isolated from dissection of the gravid females filled by eggs. After that, dehydrated and cleared according to the procedures above, for permanent preparations. The measurements are reported as $\mu \mathrm{m}$, except when specified in milimeter. In the description the range followed by the mean and standard deviation value of the measurements of structures measured within parentheses is provided. The new species was classified according to AMIN (1987). The test $t$ followed ZAR (1996) and was considered significant to $\mathrm{p}<0.05$. The ecological terms follow MARGOLIS et al. (1982).

\section{RESULTS}

\section{Neoechinorhynchus pimelodi sp.n.}

Figs $1-5$

Description based on 10 males, 20 mature and gravid female and 4 young female specimens mounted in toto:

General. Dimensions larger in the females than in the males (length: $t=7.6$; width: $t=-6.4)$ were significant $(\mathrm{p}<0.01)$. Trunk elliptic, wider in the post-equatorial portion (Fig. 1). Equal thickness of the ventral and dorsal tegument. Five gigantic hypodermic dorsal nuclei and a ventral one, irregular in shape (Fig. 1), varying in number of giant dorsal nuclei in four males and four females that present four nuclei, and in two males and two females that present three nuclei. The proboscis is slightly wider than long. Proboscis hooks arranged in three circles of different sizes. In the anterior circle, the hooks are larger, curved, with single roots. In the second circle, the hooks are smaller and only slightly curved, with small roots, intermediate in size and shape between the hooks in the first circle and the hooks in the third circle, which are smaller and almost straight, with very small roots (Figs 2a-c). Neck elongated, in the males, juveniles and matures females, and could be twice or more, as long as than proboscis in the gravid females. It is limited apically by conspicuous line, immediately bellow the third circle of hooks, including the specimens with retracted proboscis, and widening at the base. The proboscis receptacle with single walls, approximately twice as long as the neck, with a nervous ganglion in the distal portion. Two lemnisci, one uninucleate and another binucleate, of approximately equal size (Fig. 1).

Males. Trunk length $1.15-1.67 \mathrm{~mm}(1.45 \mathrm{~mm} / 0.20)$ and width $400-850$ (623/144). Proboscis length 102-125 (111/8.84) and width 107-125 (116/6.56). Hook length 100-112 (105/4.64) and width 17.5-20 (18.5/1.36) in the anterior circle, $32-40(36 / 2.32)$ and width $7.5-10(8 / 1.29)$ in the middle circle and 20-27 (23/2.80) 


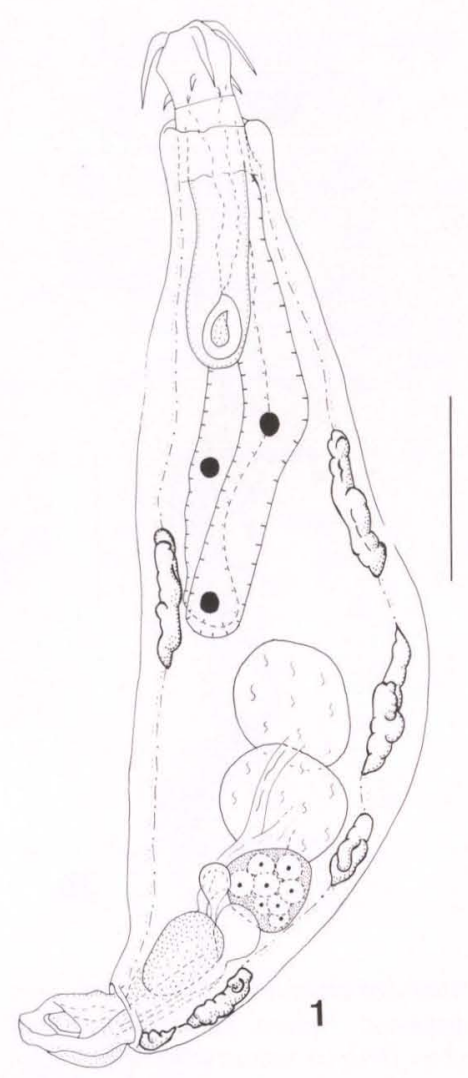

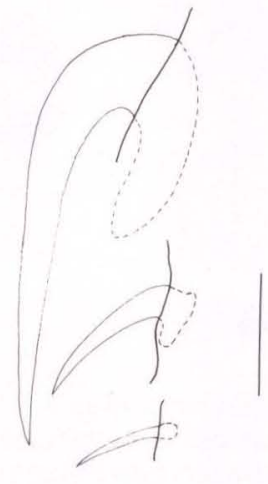

$2 b$

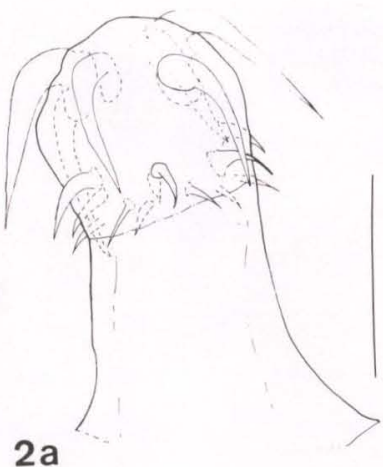

$2 \mathrm{a}$

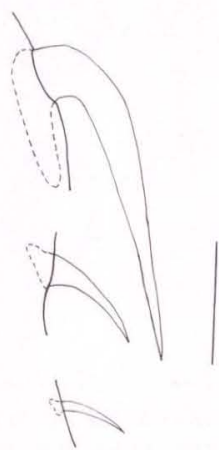

2c

Figs 1-2. Neoechinorhynchus pimelodi sp.n. infecting Pimelodus maculatus. (1) Lateral view of a male (holotype), scale-bar: $250 \mu \mathrm{m}$; (2a) proboscis of mature female, scale-bar: $125 \mu \mathrm{m}$; $(2 \mathrm{~b}, \mathrm{c})$ lateral view of the hooks of each circle of the female and male specimens respectively, scales-bars: $40 \mu \mathrm{m}$.

and width (2.5/0.0) in the posterior circle (Fig. 2b). Neck length 112-170 (128/20.91) and width 100-170 (120/30.50) at the base (Fig. 2a). Length of the proboscis receptacle 260-411 (354/57.12) and width 75-98 (84/10.15). Uninucleate lemniscus length 588-823 (677/85.39) and width 78-112 (97/12.98); binucleate lemniscus length 588-823 (667/90.83) and width 68-127 (100/20.20), at times exceeding the anterior margin of the anterior testis in the direction of its length. The reproductive system occupies the posterior half of the trunk, occupying 30-58\% (50.73\%) of the total trunk length. Rounded and contiguous testes, anterior testis length 156-343 (235/59.55) and width 157-312 (229/58.54); posterior testis length 137-274 (194/51.26) and width 162-294 (219/46.76); cement gland with eight giant nuclei, smaller than the testes, 68-254 (162/62.11) in length by 107-264 (189/55.44) in width, with a rounded cement reservoir measuring 68-166(109/36.00) in length by 

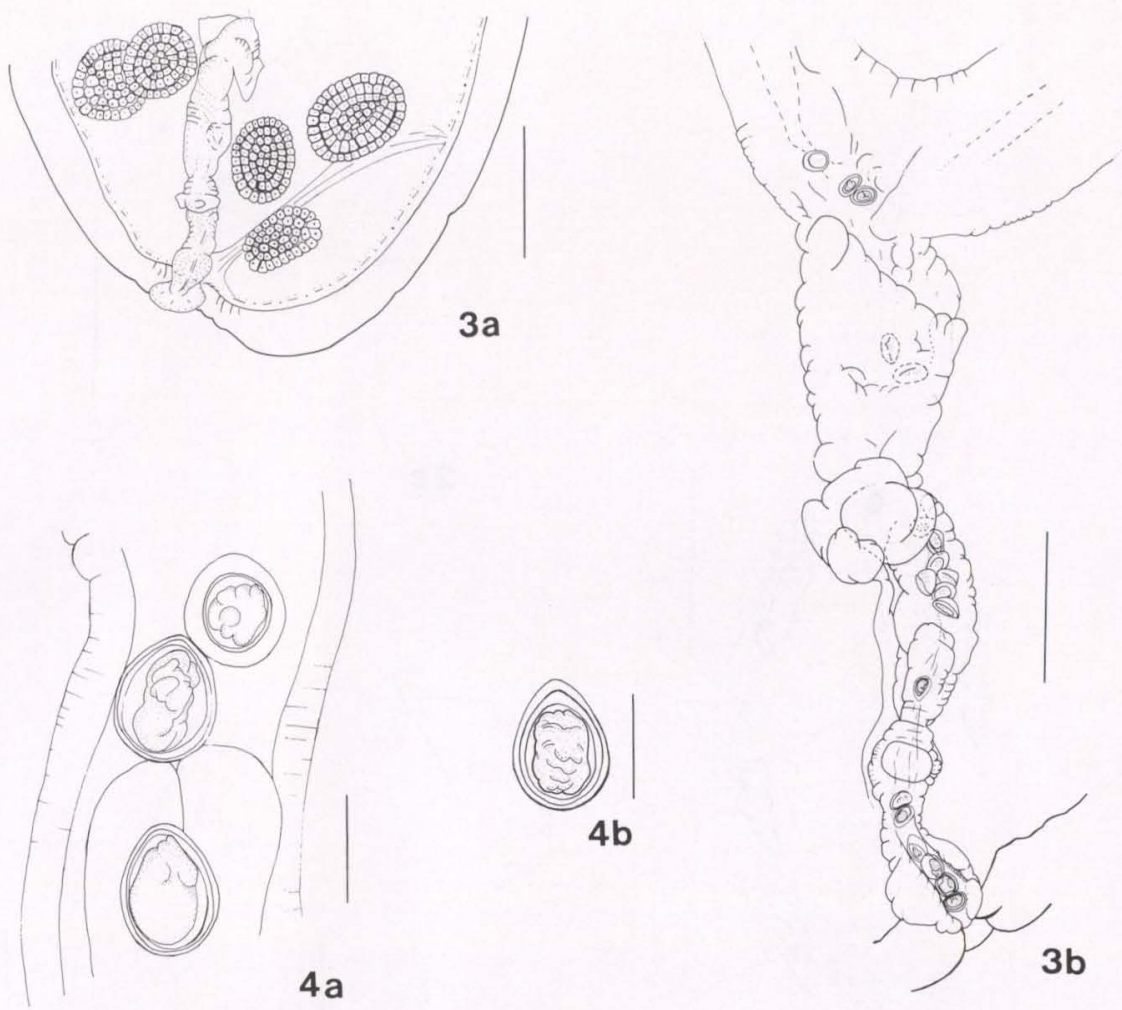

Figs 3-4. Neoechinorhynchus pimelodi sp.n. infecting Pimelodus maculatus. (3a) Lateral view of the mature female reproductive system (allotype), scale-bar: $125 \mu \mathrm{m}$; (3b) gravid female reproductive system: ligamentars sacs before the uterine bell, terminal uterus with mature eggs selected, sphincter, and vagina with eggs with acanthor near to genital pore, scale-bar: $100 \mu \mathrm{m}$; (4a) eggs from the gravid female; (4b) egg selectioned with acanthor slowly elongated, scales-bars: $15.6 \mu \mathrm{m}$.

58-127 (93/27.68) in width; Saefftigen bursa elongated measuring 125-245 (186/37.76) in length and 72-107 (92/13.87) in width; sacculiform seminal vesicle length 50-107 (82/20.09) and width 25-78 (48/19.19). Lateral seminal duct and seminal vesicle (dual in the some males) located ventrally to the cement and Saefftigen bursa system. Genital pore terminal (Figs 1, 5).

Females. Trunk length $1.18-3.97 \mathrm{~mm}(2.44 \mathrm{~mm} / 0.67)$ and width $556-1.6 \mathrm{~mm}$ $(1.09 \mathrm{~mm} / 0.28)$. Proboscis length 122-161 (137/11.52) and width $120-253$ (158/28.18). Length of the hooks in the anterior circle 102-142 (129/10.01) and width 20-30 (23/4.40), in the middle circle 34-55 (47/5.36) and width 10-12 (11/1.0), and in the third circle 27-35 (29/2.52) and width 2.5-5 (4/1.1) (Fig. 2c). Elongated neck length 175-313 (242/42.03) and width 125-282 (201/42.57) at the base. Length of the proboscis receptacle 245-565 (464/76.08) and width 117-191 $(149 / 22.13)$. Uninucleate lemniscus length $707-2.12 \mathrm{~mm}(1.31 / 0.31 \mathrm{~mm})$ and width $100-222(171 / 31.19)$; binucleate leminscus length $727-2.07 \mathrm{~mm}(1.33 / 0.31 \mathrm{~mm})$ and 


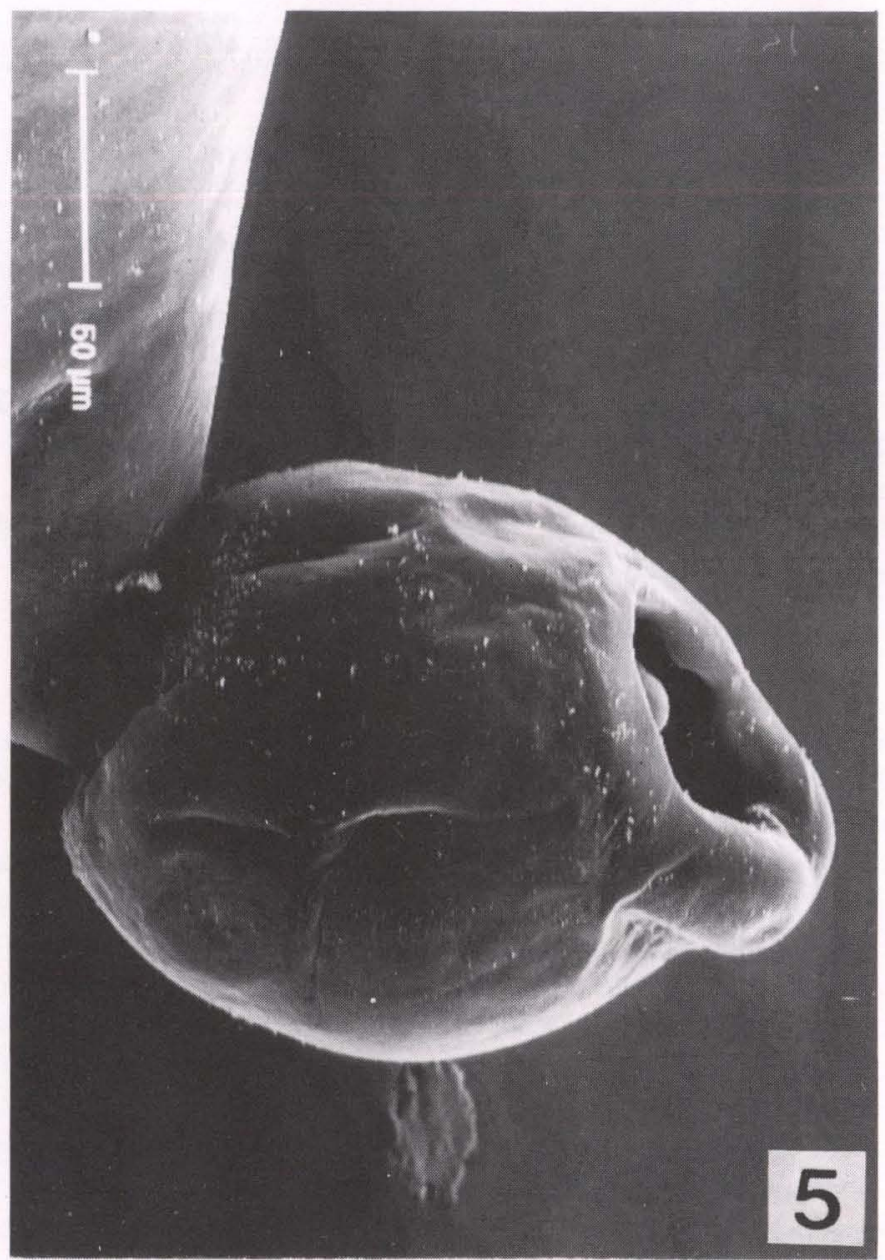

5. Neoechinorhynchus pimelodi sp.n. SEM photograph. Aspect ventral-lateral of copulatory bursa extended.

width 137-250 (182/34.27). Short reproductive system occupying 8-15\% (11.75\%) and $5-13 \%(9.25 \%)$ of the total trunk length in young and adult females, respectively. Uterine bell length 115-207 (154/35.94) and width 100-160 (122/26.36); egg selecting apparatus length 45-109 (68.77/25.11); terminal uterus length 27-40 (33.22/4.71); vagina with a sphincter separating it from the uterus measuring 37-76 (57.10/11.03). Developed germ balls measuring 62-177 (100.92/33.73) in length by $50-177(92.56 / 34.55)$ in width; number of germinal balls ranging from 47 to 112 (80/19.6); subterminal genital pore in young females and adult females, more ventral in the latter (Fig. 3a). The eggs are ovoidal in shape, measuring 15-22 (18/1.77) in length by $12-15$ (14/1.36) in width, with membranes in concentric layers in fully developed eggs (Figs $3 \mathrm{~b}, 4 \mathrm{a}-\mathrm{b}$ ) and acanthor globose to slowly elongated in shape. 
Type-host. Pimelodus maculatus Lacépède, 1803, "mandi-amarelo".

Site of infection: anterior intestine.

Prevalence: $38 \%$ (42\% in July 1995 and $34 \%$ in January 1996).

Type-locality: São Francisco River basin, Três Marias, Minas Gerais, Brazil.

Type-specimens: 33718a holotype, 33718b allotype, 33718c-e paratype numbers - Helminthologic Collection of Fundação Oswaldo Cruz (FIOCRUZ); 86929-86932 paratype numbers - United State National Parasite Collection (USNPC).

Etymology. The specific epithet refers to the generic name of the host.

Other specimens studied: Neoechinorhynchus paraguayensis $\mathrm{n}^{\circ} 75121$, a female and a male of voucher specimens (USNPC), and $N$. pterodoridis, numbers 024B allotype and 024C paratype, Invertebrate Collection of the National Institute of Research of the Amazon Region (INPA).

\section{DISCUSSION}

Among the Acanthocephala from freshwater fish species of Brazil, those recorded in the Amazon Region and cited by THATCHER (1991) are the species that most closely resemble $N$. pimelodi.

Neoechinorhynchus buttnerae Golvan, 1956 was originally collected from Myletes macropomis Kner, in the Amazon River, and later from Colossoma nigripinnis (Cope) in the same river in Colombia by ScHMidT \& Hugghins (1973). Neoechinorhynchus pimelodi differs from $N$. buttnerae because the latter presents larger males and females, by the absence of a neck, and by the larger size of the hooks of the proboscis, especially those in the second and third circles, in both sexes. In addition, the latter species presents two large seminal vesicles located anteriorly to the cement reservoir and a sensory papilla on each side of the neck after the last circle of hooks, as reported by SCHMIDT \& HUGGHINS (1973).

Neoechinorhynchus pimelodi differs from $N$. paraguayensis Machado Filho, 1959 , originally collected from a "peixe-martin" (specific name of the host was not stated by the author) from the Rio Paraguay and from Geophagus brasiliensis from the Guandu-Açu River, Rio de Janeiro, by NICKOL \& PADILHA (1979), and from $N$. pterodoridis Thatcher, 1981 from Pterodoras granulosus (Valenciennes) from the Amazon River, Manaus, especially by smaller size and greater width of the eggs (18x14) compared to the eggs of these two species (29x12 and 24-27x7-9, respectively). Selected eggs of $N$. pimelodi present concentric layers of fine texture involving the acanthor, while those of $N$. paraguayensis, present clear radial grooves in the most external layer. The new species also differs from $N$. paraguayensis by presenting larges sizes of the hooks of the proboscis, especially those in the first and second circles in males, and the second and third circles in females; $N$. pimelodi also present a distinct and elongated neck, could be twice as long as than the proboscis in the gravid females, lemniscus length almost three times greater in females, and by smaller gonads and by the fact that the reproductive system of the male occupies only $50 \%$ of the length of the trunks as opposed to $70 \%$ in $\mathrm{N}$. paraguayensis. 
Furthermore, the dimensions of the cement gland and Saefftigen bursa of $N$. pimelodi are smaller than those of voucher specimen of $N$. paraguayensis ( 375 in length by 343 in width and 254 in length, respectively according to our observations from voucher specimen). Neoechinorhynchus pimelodi also differs from N. pterodoridis described by THATCHER (1981) by the dimensions of the hooks: the hooks in the first circle are shorter in both sexes, those of the second circle are shorter in males, and those in the third circle are larger in both sexes. The lemnisci of the new species are more extensive in both sexes, reaching the equatorial region of the trunk or even exceeding it; in the males they reach the gonads and in the females they are almost three times as long as in $N$. pterodoridis. The size of the cement gland is smaller than the size of the testes, whereas in $N$. pterodoridis it is larger than the size of the gonads; the cement reservoir and the Saefftigen bursa are also smaller and the male reproductive system occupies 30 to $58 \%$ of the total length of the trunk in the new species, whereas the largest dimensions of these structures in $N$. pterodoridis occupy, as a whole, 60 to $73 \%$ of the trunk length.

YAMAGUTI (1963) cited the presence of N. macronucleatum Machado Filho, 1954 and N. spectabilis Machado Filho, 1959 in freshwater fish of Brazil, as well as $N$. buttnerae, as reported by THATCHER (1991). Although MACHADO FiLHO (1954) used the correct nomenclature in the original publication of the nominal taxon, the specific name $N$. macronucleatum used by YAMAGUTI (1963) was corrected by GoLVAN (1994) in order to agree with the male generic name. Thus, $N$. pimelodi differs from $N$. macronucleatus collected from Licengraulis $\mathrm{sp}$. in the Juparanã pond, Espirito Santo, because the latter species has larger trunk dimensions for both males and females, salient and contiguous giant dorsal hypodermic nuclei, a smaller proboscis, the absence of a clearly visible neck, hooks in three smaller circles, elongated gonads, and smaller eggs. Neoechinorhynchus spectabilis collected from Curimata elegans Steind. in Emas, Pirassununga, São Paulo by MACHADO FILHO (1959) was transferred to the genus Gorytocephalus created by NICKOL \& THATCHER (1971) to include acantocephalan species with the same number of hooks but presenting thickening of the dorsal tegumentum forming a fold in the region of insertion of the proboscis.

Among the species occurring in Brazil cited by GoLVAN (1994) but not by ThAtcher (1991), N. curemai Noronha, 1973 was collected from Prochilodus scrofa Steindachner in the Amazon River, in Pará (NORONHA 1984), and later from the same host in the Mogi-Guassu River, Pirassununga, São Paulo, by KoHN et al. (1985). Neoechinorhynchus pimelodi differs from N. curemai because the latter presents a fusiform and elongated trunk shape, absence of a neck, absence of nuclei in the lemnisci and different hook sizes in the proboscis, with first circle lateral hooks larger than the middle hooks in the same circle and larger dimensions of the structures of the reproductive system of both sexes and of the eggs.

Neoechinorhynchus pimelodi differs from $N$. golvani Salgado-Maldonado, 1978 collected from the Amazon River mainly by the larger hooks in the three circles and a clearly visible neck.

Golvan (1994) did not list N. villoldoi Vizcaino, 1992, in the genus Neoechinorhynchus, although this species collected from Corydoras paleatus

Revta bras. Zool. 15 (4): 1003 - 1011, 1998 
(Jenyns, 1842) Eigenmann \& Eigenmann, 1888, from the Province of Buenos Aires, Argentina, was described by VIzCAINo (1992) as a species close to those found in freshwater fish of Brazil and cited above. Neoechinorhynchus pimelodi differs from $N$. villoldoi by being larger and having a wider trunk in males, by having longer lemnisci exceeding the proboscis receptacle by at least twice its length, by the larger size of the hooks of the proboscis in the first and second circles and by the smaller size of the eggs.

The present study represent the first record of Acanthocephala in Pimelodus maculatus Lacépède, 1803, collected from the São Francisco River, Minas Gerais, Brazil.

ACKNOWLEDGEMENTS. The authors wish to thank the biologist Yoshimi Sato, CODEVASF, Três Marias, Minas Gerais, Brazil, for the collection and identification of the hosts, and CODEVASF for logistic support during the study. Thanks are also due to Dr. James C. Chubb and Mr. C. J. Veltkamp, University of Liverpool, Liverpool, England, for the SEM photograph, to Dr. Celso Magalhães, curator of the Invertebrate Collection of INPA, Amazonas, Brazil, for the loan of the paratypes examined, to Dr. J. Ralph Lichtenfels, United States Department of Agriculture, Beltsville, Maryland, USA, for the loan of voucher specimens and for depositing type specimens at USNPC, and to Dr. Dely Noronha, Helminthologic Collection of FIOCRUZ. Rio de Janeiro, Brazil, for depositing type specimens.

\section{REFERENCES}

AMIN, O.M. 1987. Key to the families and subfamilies of Acanthocephala with the erection of a new class (Polyacanthocephala) and a new order (Polyacanthorhynchida). Jour. Parasitol. 73: 1216-1219.

BRITSKI, H.A.; Y. SATO \& A.B.S. RosA. 1984. Manual de identificação de peixes da região de Três Marias (Com chaves de identificação para os peixes da bacia do rio São Francisco). Brasília, Câmara dos Deputados, Coordenação de Publicação - CODEvasf, Divisão de Piscicultura e Pesca, 143p.

Golvan, Y.J. 1994. Nomenclature of the Acanthocephala. Res. Rev. Parasit. 54: 135-205.

KoHN, A.; B.M.M. Fernandes; B. MACEDO \& B. ABRAMSON. 1985. Helminths parasites of freshwater fishes from Pirassununga, SP, Brazil. Mem. Inst. Oswaldo Cruz 80: 327-336.

MACHADO FiLHO, D.A. 1954. Uma nova espécie do gênero Neoechinorhynchus (Hamann) (Neoechinorhynchidae, Acanthocephala). Rev. Brasil. Biol. 14: 5557.

1959. "Neoechinorhynchus spectabilis" sp.n. (Neoechinorhynchidae, Acanthocephala). Rev. Brasil. Biol. 19: 191-194.

MARGOLIS, L.; G.W. ESCH; J.C. Holmes; A.M. KuRIS \& G.A. SCHAD. 1982. The use of ecological terms in parasitology (report of an ad hoc committee of the American Society of Parasitologists). Jour. Parasitol. 68: 131-133.

NicKOL, B.B. \& T.N. PADILHA. 1979. Neoechinorhynchus paraguayensis (Acanthocephala: Neoechinorhynchidae) from Brazil. Jour. Parasitol. 65: 987-989. 
Nickol, B.B. \& V.E. ThatCHER. 1971. Two new acanthocephalans from neotropical fishes: Neoechinorhynchus prochilodorum sp.n. and Gorytocephalus plecostomorum gen. et sp.n. Jour. Parasitol. 57: 576-581.

NoRONHA, D. 1984. Remarks on Neoechinorhynchus curemai Noronha, 1973 (Eoacanthocephala, Neoechinorhynchidae). Mem. Inst. Oswaldo Cruz 79: 271.

SCHMidT, G.D. \& E.J. HugGHINS. 1973. Acanthocephala of South american fishes. Part I. Eoacanthocephala. Jour. Parasitol. 59: 829-835.

THATCHER, V.E. 1981. Neoechinorhynchus pterodoridis n.sp. (Acanthocephala: Neoechinorhynchidae) do bacu liso (Pterodoras granulosus) da Amazônia Brasileira. Acta Amazônica 11: 445-448.

- 1991. Amazon Fish Parasites. Amazoniana 11: 263-572.

VizCAÍNO, S.I. 1992. Especie nueva del gênero Neoechinorhynchus (Acanthocephala-Neoechinorhynchidae) parásita de peces de Argentina. An. Inst. Biol. Univ. Nac. Autón. México, Zool., 63: 179-184.

Yamaguti, S. 1963. Systema Helminthum. IV. Acanthocephala. New York, Interscience Publishers, John Wiley \& Sons Inc., 423p.

ZAR, J.H. 1996. Biostatistical Analysis. New Jersey, Prentice Hall Inc., $3^{\text {rd }}$ ed., $662 \mathrm{p}$.

Recebido em 01.VIII.1998; aceito em 24.XI.1998. 